\title{
PENGARUH EKUITAS MEREK TERHADAP REPURCHASE INTENTION HANDPHONE MEREK SAMSUNG KEPADA MAHASISWA FAKULTAS EKONOMI UNIVERISTAS TADULAKO DI KOTA PALU
}

\author{
SYARIFUDDIN NURSYAMSU \\ SYAMSUL BAHRI DP \\ SURYADI HADI \\ Prodi Manajemen, Fakultas Ekonomi, Universitas Tadulako \\ Email: nursyamsusyarifuddin@gmail.com
}

\begin{abstract}
This study aims to determine how much the brand equity effect to repurchase intention Samsung brand mobile phone to the students of the faculty of economics Tadulako University, Palu. The research method used is descriptive of causal method with a sample of 75 people with non-probability sampling technique with a purposive sampling approach and Multiple Linear Regression Analysis method with the aid of a computer program SPSS for Windows Release 16.0. The results showed that: 1). brand equity consists of brand awareness, perceived quality, brand association and brand loyalty simultaneously affect significantly on repurchase intention Samsung brand mobile phone to the students of the faculty of economics Tadulako University, Palu; 2). Brand awareness partially have no significant effect on repurchase intention Samsung brand mobile phone to the students of the faculty of economics Tadulako in Palu; 3). Perceived quality, brand association, and brand loyalty is partially affect significantly on repurchase intention Samsung brand mobile phone to the students of the faculty of economics Tadulako in Palu.
\end{abstract}

Keywords: Brand Equity, Repurchase Intention, Samsung Mobile Phones

\begin{abstract}
Abstrak
Penelitian ini bertujuan untuk mengetahui seberapa besar efek ekuitas merek untuk membeli kembali niat merek ponsel Samsung kepada mahasiswa fakultas ekonomi Universitas Tadulako, Palu. Metode penelitian yang digunakan adalah deskriptif metode kausal dengan sampel 75 orang dengan teknik non probability sampling dengan pendekatan purposive sampling dan metode Analisis Regresi Linier Berganda dengan bantuan program komputer SPSS for Windows Release 16.0. Hasil penelitian menunjukkan bahwa: 1). Ekuitas merek terdiri dari brand awareness, perceived quality, brand association dan brand loyalty sekaligus berpengaruh secara signifikan terhadap niat membeli kembali merek ponsel Samsung kepada mahasiswa fakultas ekonomi Universitas Tadulako, Palu; 2). Kesadaran merek sebagian tidak berpengaruh signifikan terhadap niat beli kembali merek ponsel Samsung kepada mahasiswa fakultas ekonomi Tadulako di Palu; 3). Kualitas yang dirasakan, asosiasi merek, dan loyalitas merek sebagian berpengaruh secara signifikan terhadap niat membeli kembali merek ponsel merek Samsung kepada mahasiswa fakultas ekonomi Tadulako di Palu.
\end{abstract}

Kata kunci: Brand Equity, Repurchase Intention, Samsung Mobile Phones

\section{PENDAHULUAN}

\section{Latar Belakang Penelitian}

Saat ini persaingan perusahaan menarik konsumen tidak lagi terbatas pada atribut fungsional produk saja misalnya kegunaan produk, melainkan sudah dikaitkan dengan merek yang mampu memberikan citra khusus bagi penggunanya. Produk menjelaskan sebagai suatu komoditi yang dipertukarkan, sedangkan merek menjelaskan spesifikasi pelanggannya. Menurut Kotler dan Keller (2008:263) menyatakan ekuitas merek adalah nilai tambah yang diberikan pada produk dan jasa. 
Ekuitas merek dapat tercermin dalam cara konsumen berpikir, merasa, dan bertindak dalam hubunganya dengan merek, dan juga harga, pangas pasar, dan profitabilitas yang diberikan merek bagi perusahaan.

Repurchase Intention atau minat beli ulang adalah keputusan terencana seseorang untuk melakukan pembelian kembali atas produk dan jasa tertentu, dengan mempertimbangkan situasi pengalaman yang terjadi setelah berbelanja melalui respon positif atau negative (Hellier et al, 2003).

Hadirnya merek-merek handphone baru dewasa ini karena banyak perusahaan menangkap adanya peluang. Kehadiran merek-merek baru ini tentunya meramaikan produk yang sudah ada, akan tetapi kehadiran para kompetitor jelas memperketat persaingan yang sudah hadir sebelumnya. Perusahaan dihadapkan pada permasalahan jumlah penjualan yang diakibatkan berpindahnya konsumen mereka ke merek handphone yang lain sehingga betapa pentingnya bagi perusahaan untuk meningkatkan ekuitas merek pada produknya, agar handphone merek Samsung tetap mampu mempertahankan dominasinya di pasar. Dimana minat pembelian ulang sangat erat kaitanya dengan berbagai pengalaman konsumen dengan merek, persepsi konsumen atas kualitas merek dan juga keinginan terus menggunakan suatu merek tertentu. Penelitian yang akan dilakukan adalah berjudul Pengaruh Ekuitas Merek Terhadap Repurchase Intention Handphone Merek Samsung Kepada Mahasiswa Fakultas Ekonomi Dan Bisnis Universitas Tadulako Melakukan Di Kota Palu.

Berdasarkan uraian permasalahan di atas, maka tujuan penelitian ini adalah "Untuk Mengetahui apakah variabel brand equity (ekuitas merek) yang terdiri dari dimensi brand awareness, perceived quality, brand association, dan brand loyalty secara serempak dan parsial berpengaruh dan signifikan terhadap repurchase intention handphone merek Samsung kepada mahasiswa Fakultas Ekonomi Universitas Tadulako di Kota Palu."

\section{KAJIAN LITERATUR DAN PENGEMBANGAN HIPOTESIS Brand Equity (Ekuitas Merek)}

Kotler dan Keller (2008:263) menyatakan brand equity adalah nilai tambah yang diberikan pada produk dan jasa. Ekuitas merek dapat tercermin dalam cara konsumen berpikir, merasa, dan bertindak dalam hubunganya dengan merek, dan juga harga, pangasa pasar, dan profitabilitas yang diberikan merek bagi perusahaan. Brand equity memberikan nilai terdiri dari empat kategori (Durianto, dkk, 2001:4) yaitu:

1. Dimensi kesadaran merek (brand awareness)

2. Dimensi kesan kualitas (Perceived quality)

3. Dimensi asosiasi (brand association)

4. Dimensi Loyalitas (brand loyalty)

\section{Kesadaran Merek (Brand Awareness)}

Menurut Darmadi Durianto dkk., (2001:54). brand awareness artinya adalah kesanggupan calon pembeli untuk mengenali atau mengingat kembali bahwa suatu merek merupakan bagaimana dari kategori merek tertentu. Peran brand awareness dalam keseluruhan brand equity tergantung dari sejauh mana tingkatan kesadaran yang dicapai oleh suatu merek.

\section{Asosiasi Merek (Brand Association)}

Menurut Darmadi Durianto dkk. (2001:68) Brand association adalah segala kesan yang muncul di benak seseorang yang terkait dengan ingatannya mengenai suatu merek. Kesan-kesan yang terkait merek akan semakin meningkat dengan semakin banyaknya pengalaman konsumen dalam mengkomunikasikan suatu merek atau dengan semakin seringnya penampakan merek tersebut dalam bauran promosinya.

\section{Persepsi Kualitas ( Perceived Quality)}

Pengertian perceived quality (kesan kualitas) menurut Darmadi Durianto dkk., (2001:96) adalah persepsi pelanggan terhadap keseluruhan atau keunggulan suatu produk atau jasa layanan berkaitan dengan maksud yang diharapkan. Perceived quality akan membentuk persepsi kualitas dari suatu produk di mata pelanggan. Hal ini dikarenakan perceived quality merupakan persepsi dari 
pelanggan maka perceived quality tidak dapat ditentukan secara objektif. Persepsi pelanggan akan melibatkan apa yang penting bagi pelanggan karena setiap pelanggan memiliki kepentingan yang berbeda-beda terhadap suatu produk atau jasa.

\section{Loyalitas Merek ( Brand loyalty)}

Brand loyalty (loyalitas merek) merupakan suatu ukuran keterkaitan pelanggan kepada sebuah merek (Darmadi Durianto, 2001:126). Brand loyalty merupakan inti dari ekuitas merek yang menjadi gagasan sentral dalam pemasaran karena hal ini merupakan suatu ukuran keterikatan pelanggan terhadap suatu merek.

\section{Minat Pembelian Ulang (Repurchase Intention)}

Menurut Simamora (2003:28), menyatakan bahwa apabila seseorang sudah pernah melakukan pembelian terhadap suatu produk dan ia akan melakukan pembelian ulang terhadap produk tersebut maka perilaku yang akan mungkin ditunjukkan ada dua yaitu:

1. Pemecahan masalah berulang

Alasan melakukan pemecahan masalah dalam pembelian ulang disebabkan oleh beberapa kemungkinan, yaitu:

a) Konsumen tidak puas dengan produk sebelumnya, sehingga memilih alternatif lainnya.

b) Pembelian pertama sudah lama akibatnya saat ingin melakukan pembelian ulang produk sudah mengalami banyak perubahan

2. Perilaku karena kebiasaan

Perilaku ini tampak pada seseorang yang membeli merek/produk yang sama berulang-ulang.

Perilaku tersebut dapat terjadi karena dua hal, yaitu:

a) Pengaruh loyalitas, dimana orang tersebut loyal terhadap merek/produk tersebut.

b) Karena kemasan, dimana seseorang membeli produk/merek yang sama karena malas mengevaluasi alternatife - alternatif yang tersedia.

Hellier et al,(2003) menyatakan bahwa repurchase intention adalah keputusan terencana seseorang untuk melakukan pembelian kembali atas jasa tertentu, dengan mempertimbangkan situasi yang terjadi dan tingkat kesukaan. Tjiptono dalam (Trisnawati, 2012) menyatakan perilaku pembelian ulang seringkali dihubungkan dengan loyalitas merek. Akan tetapi, ada perbedaan di antara keduanya, bila loyalitas untuk mencerminkan komitmen psikologis terhadap merek tertentu, maka perilaku pembelian ulang semata-mata menyangkut pembelian merek tertentu yang sama secara berulang kali.

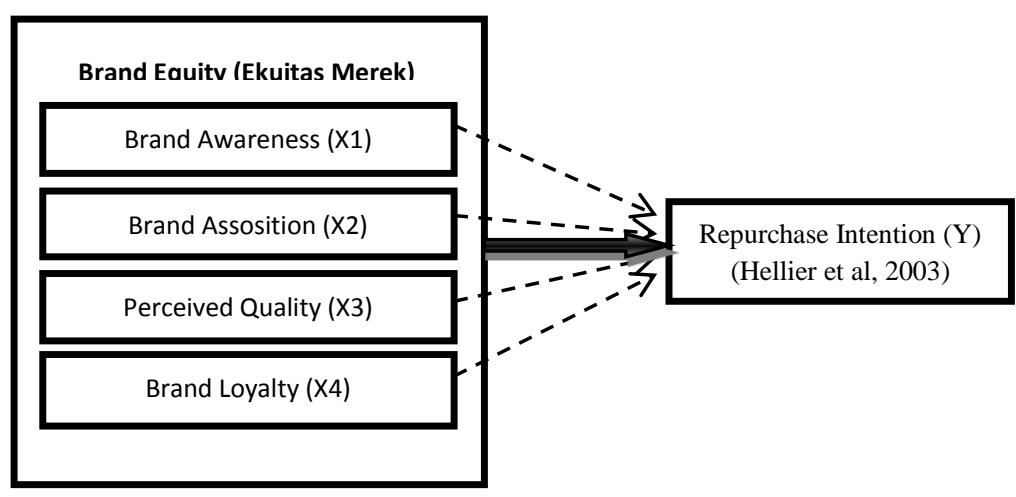

Gambar. 1 Kerangka Pemikiran

\section{Hipotesis}

1. Variabel ekuitas merek yang terdiri dari dimensi brand awareness, brand association, perceived quality, dan brand loyalty secara serempak berpengaruh dan signifikan terhadap repurchase intention handphone merek Samsung kepada mahasiswa Fakultas Ekonomi Universitas Tadulako di Kota Palu. 
2. Ekuitas merek dimensi brand awareness secara parsial berpengaruh dan signifikan terhadap repurchase intention handphone merek Samsung kepada mahasiswa Fakultas Ekonomi Universitas Tadulako di Kota Palu.

3. Ekuitas merek dimensi brand association secara parsial berpengaruh dan signifikan terhadap repurchase intention handphone merek Samsung kepada mahasiswa Fakultas Ekonomi Universitas Tadulako di Kota Palu.

4. Ekuitas merek dimensi perceived quality secara parsial berpengaruh dan signifikan terhadap repurchase intention handphone merek Samsung kepada mahasiswa Fakultas Ekonomi Universitas Tadulako di Kota Palu.

5. Ekuitas merek dimensi brand Loyalty secara parsial berpengaruh dan signifikan terhadap repurchase intention handphone merek Samsung kepada mahasiswa Fakultas Ekonomi Universitas Tadulako di Kota Palu.

\section{METODE PENELITIAN}

\section{Tipe Penelitian}

Tipe penelitian yang digunakan dalam penelitian ini bersifat deskriptif kausal dengan alasan peneliti akan menggambarkan secara sistematis sejauhmana hubungan serta pengaruh dari variable independen dalam hal ini adalah ekuitas merek (brand equity) yang terdiri dari : brand awareness ( kesadaran merek ), perceived quality ( kesan kualitas ), brand association ( asosiasi merek ) dan brand loyalty ( loyalitas merek ) terhadap variabel dependen dalam hal ini yaitu repurchase intention handphone merek Samsung kepada mahasiswa fakultas ekonomi Universitas Tadulako di Kota Palu.

\section{Populasi dan Penarikan Sampel Populasi}

Populasi pada penelitian ini adalah mahasiswa Fakultas Ekonomi Universitas Tadulako di kota palu yang menggunakan handphone merek Samsung.

\section{Sampel}

Menurut Sugiyono (2014:116) sampel adalah bagian dari jumlah dan karakteristik yang dimiliki oleh populasi tersebut. Mengingat jumlah populasi dalam penelitian ini tidak diketahui secara pasti, dikarenakan tidak adanya data pendukung yang mencatat jumlah secara pasti mahasiswa pengguna produk handphone merek Samsung di Fakultas Ekonomi Universitas Tadulako, maka besanya sampel pada penelitian ini merujuk pada teori Roscoe dalam Sugiyono (2014:130) yang menyatakan bahwa bila dalam penelitian akan melakukan analisis dengan multivariate (korelasi atau regresi ganda misalnya), maka jumlah anggota sampel adalah minimal 10 kali dari jumlah variabel yang diteliti (variabel independen + variabel dependen). Jumlah variabel dalam penelitian ini adalah 5 yang terdiri dari variabel independen (brand awareness, brand association, perceived quality, dan brand loyalty) dan variabel dependen (repurchase intention). Pada penelitian ini penulis menetapkan jumlah sampel sebesar $15 \times 5$ variabel yaitu 75 responden, dengan demikian sampel dari penelitian ini adalah sebanyak 75 orang responden.

\section{Teknik penarikan sampel}

Dari perhitungan jumlah sampel diatas ditetapkan sejumlah sampel sebanyak 75 orang dengan teknik penarikan dalam penelitian ini adalah teknik non probability sampling dengan pendekatan purposive sampling yaitu peneliti telah menetapkan kriteria sampel yang diharapkan. Oleh karna itu, hanya orang-orang yang memenuhi kriteria yang telah ditetapkan itu yang akan dijadikan sampel. Adapun kriteria responden yang dijadikan sampel pada penelitian ini adalah :

1. Merupakan Mahasiswa Fakultas Ekonomi dan Bisnis UNTAD

2. Merupakan Mahasiswa pengguna Handhone Samsung

3. Lama penggunaan Handphone Samsung telah mencapai atau lebih dari 1 tahun 


\section{Definisi Operasional Variabel}

Demi menunjang keberhasilan penelitian, maka terlebih dahulu ditentukan variabelnya.dalam operasional variabel ini, peneliti menggunakan beberapa variabel pengujian yang dikelompokkan menjadi :

1. Variabel Independen (X)

Variabel independen yaitu variabel yang mempengaruhi atau menjadi sebab perubahanya atau timbulnya variabel dependen (variabel terikat).

A. Kesadaran merek (brand awareness) (X1)

1. Ingatan terhadap merek

2. Ingatan terhadap iklan

3. Kemampuan pelanggan mengingat model varian

4. Ciri chas yang membedakan produk

B. Persepsi kualitas (Perceived Quality) (X2)

1. Inovasi jenis/tipe

2. Ketahanan produk

3. Fitur yang menarik

4. Kualitas produk dibandingkan dengan merek lain

C. Asosiasi merek (X3)

1. Inovasi desain model dan teknologi

2. Kualitas suara yang memuaskan

3. Pencitraan merek produk di benak konsumen

4. Kesesuaian terhadap gaya hidup

D. Loyalitas merek (X4)

1. Setia menggunakan merek

2. Switching barrier

3. Ketidaktertarikkan terhadap merek lain

4. Kepuasan terhadap merek

2. Variabel dependen

Variabel dependen merupakan variabel yang dipengaruhi atau yang menjadi akibat, karena adanya variabel independen. Variabel depeden dalam penelitian ini adalah repurchase intention atau minat pembelian ulang, adapun indikator dari variabel repurchase intention pada penelitian ini mengacu pada teori Hawkins dalam (Puspitasari, 2011) yaitu:

a. Mereferensikan produk tersebut ke orang lain

b. Keinginan untuk menggunakan produk yang sama

c. Pembelian ulang berdasarkan evaluasi produk yang baik

\section{Analisis Regresi Linear berganda}

Dalam penelitian ini peneliti menggunakan analisis regresi linear berganda. untuk mengetahui besarnya pengaruh secara kuantitatif dari suatu perubahan kejadian (variabel X) terhadap kejadian lainnya (variabel Y). Dalam penelitian ini, analisis regresi berganda berperan sebagai teknik statistik yang digunakan untuk menguji ada tidaknya pengaruh brand equity terhadap repurchase intention. Analisis regresi menggunakan rumus persamaan regresi berganda seperti yang dikutip dari Sugiyono (2010:277) yaitu:

$$
\mathrm{Y}=\mathrm{a}+\mathrm{b}_{1} \mathrm{X}_{1}+\mathrm{b}_{2} \mathrm{X}_{2}+\ldots \ldots . .+\mathrm{bnXn}+\mathrm{e}
$$

Apabila rumus tersebut diaplikasikan kedalam penelitian ini, maka regresi linear berganda dengan formulasi sebagai berikut :

$$
\mathrm{Y}=\mathrm{a}+\mathrm{b}_{1} \mathrm{X}_{1}+\mathrm{b}_{2} \mathrm{X}_{2}+\mathrm{b}_{3} \mathrm{X}_{3}+\mathrm{b}_{4} \mathrm{X}_{4}+\mathrm{e}
$$

Dimana :

$\mathrm{Y}=$ Repurchase Itention (Variabel dependen/terikat)

$\mathrm{X} 1=$ Brand awareness ( (variabel independen/bebas) 


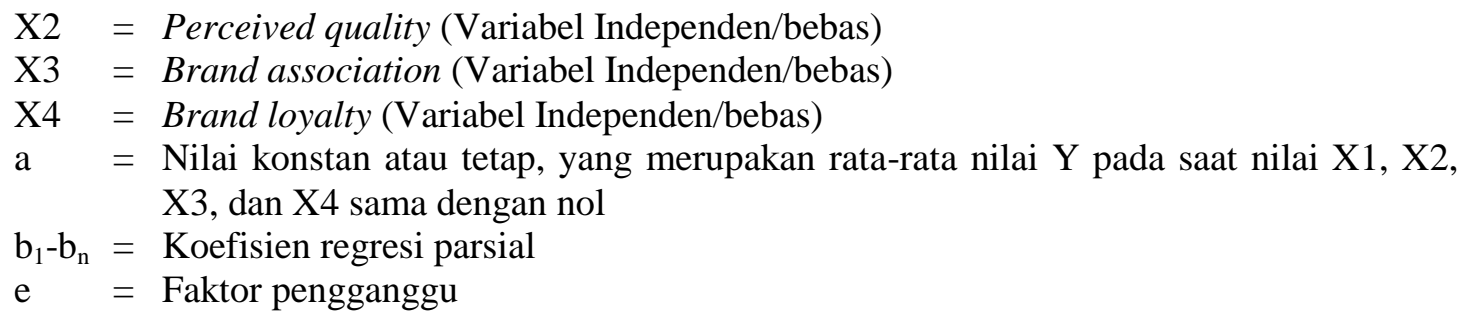

\section{Pengujian hipotesis pertama ( ujiserempak/uji-F)}

Selanjutnya untuk menguji keberartian dari koefisien regresi secara keseluruhan digunakan statistik uji-F secara serempak yang pengujian hipotesisnya adalah sebagai berikut:

Adapun kaidah pengambilan keputusan adalah sebagai berikut:

a. Jika $\mathrm{F}_{\text {hitung }}>\mathrm{F}_{\text {tabel }}$ pada tingkat kepercayaan $95 \%(\alpha=0.05)$ maka terbukti semua variabel independen yang diamati secara serempak berpengaruh signifikan terhadap variabel dependen.

b. Jika $F_{\text {hitung }}<\mathrm{F}_{\text {tabel }}$ pada tingkat kepercayaan $95 \%(\alpha=0.05)$ maka terbukti semua variabel independen yang diamati secara serempak tidak berpengaruh signifikan terhadap variabel dependen.

\section{Pengujian Hipotesis kedua (Uji Parsial/uji-T)}

Untuk menguji keberartian dari tiap-tiap variabel bebas akan kontribusinya terhadap perubahan variabel terikat, digunakan uji statistik (t-test). Adapun kaidah pengambilan keputusan adalah sebagai berikut:

a. Jika $t_{\text {hitung }}>t_{\text {tabel }}$ pada tingkat kepercayaan 95\% $(\alpha=0,05)$ maka terbukti bahwa variabel independen secara parsial berpengaruh signifikan terhadap variabel dependen.

b. Jika $t_{\text {hitung }}<t_{\text {tabel }}$ pada tingkat kepercayaan 95\% $(\alpha=0,05)$ maka terbukti bahwa variabel independen secara parsial tidak berpengaruh signifikan terhadap variabel dependen.

\section{HASIL DAN PEMBAHASAN}

Penilaian 75 responden tentang pengaruh ekuitas merek terhadap repurchase intention handphone merek Samsung kepada mahasiswa fakultas ekonomi universitas tadulako di kota Palu :

Tabel 1 Jawaban Responden Terhadap Indikator

Pertanyaan/Pernyataan Dimensi Kesadaran Merek $\left(\mathrm{X}_{1}\right)$

\begin{tabular}{|c|c|c|c|c|c|c|c|c|c|c|c|}
\hline \multirow{3}{*}{ Indikator } & \multicolumn{11}{|c|}{ Tanggapan Responden } \\
\hline & \multicolumn{2}{|c|}{ SS } & \multicolumn{2}{|c|}{$\mathbf{S}$} & \multicolumn{2}{|c|}{$\mathbf{N}$} & \multicolumn{2}{|c|}{ TS } & \multicolumn{2}{|c|}{ STS } & \multirow{2}{*}{ Mean } \\
\hline & $\sum$ & $\%$ & $\sum$ & $\%$ & $\sum$ & $\%$ & $\sum$ & $\%$ & $\sum$ & $\%$ & \\
\hline $\mathrm{X} 1.1$ & 3 & 4.0 & 36 & 48.0 & 25 & 32.0 & 11 & 14.7 & 1 & 1.3 & 3.4500 \\
\hline $\mathrm{X} 1.2$ & 7 & 9.3 & 52 & 69.3 & 10 & 13.3 & 5 & 6.7 & 1 & 1.3 & 3.5500 \\
\hline X1.3 & 9 & 12.0 & 37 & 49.3 & 23 & 30.7 & 6 & 8.0 & 0 & 0.0 & 4.0500 \\
\hline $\mathrm{X} 1.4$ & 17 & 22.7 & 38 & 50.7 & 17 & 22.7 & 3 & 4.0 & 0 & 0.0 & 3.8500 \\
\hline
\end{tabular}

Secara keseluruhan diketahui bahwa jawaban responden terhadap variabel kesadaran merek adalah mereka setuju bahwa variabel ini mempengaruhi repurchase intention. 
Tabel 2 Jawaban Responden Terhadap Indikator

Pertanyaan/Pernyataan Dimensi Persepsi Kualitas $\left(\mathrm{X}_{2}\right)$

\begin{tabular}{|c|c|c|c|c|c|c|c|c|c|c|c|}
\hline \multirow{3}{*}{ Indikator } & \multicolumn{11}{|c|}{ Tanggapan Responden } \\
\hline & \multicolumn{2}{|c|}{ SS } & \multicolumn{2}{|c|}{$\mathbf{S}$} & \multicolumn{2}{|c|}{$\mathbf{N}$} & \multicolumn{2}{|c|}{ TS } & \multicolumn{2}{|c|}{ STS } & \multirow{2}{*}{ Mean } \\
\hline & $\sum$ & $\%$ & $\sum$ & $\%$ & $\sum$ & $\%$ & $\sum$ & $\%$ & $\sum$ & $\%$ & \\
\hline $\mathrm{X} 2.1$ & 11 & 14.7 & 33 & 44.0 & 13 & 17.3 & 15 & 20.0 & 3 & 4.0 & 2.9500 \\
\hline $\mathrm{X} 2.2$ & 6 & 8.0 & 25 & 33.3 & 24 & 32.0 & 16 & 21.3 & 4 & 5.3 & 3.5500 \\
\hline X2.3 & 13 & 17.3 & 51 & 68.0 & 10 & 13.3 & 1 & 1.3 & 0 & 0.0 & 4.0500 \\
\hline $\mathrm{X} 2.4$ & 20 & 26.7 & 43 & 57.3 & 11 & 14.7 & 1 & 1.3 & 0 & 0.0 & 4.2000 \\
\hline
\end{tabular}

Secara keseluruhan diketahui bahwa jawaban responden terhadap variabel persepsi kualitas adalah mereka setuju bahwa variabel ini mempengaruhi repurchase intention.

Tabel 3 Jawaban Responden Terhadap Indikator

Pertanyaan/Pernyataan Dimensi Asosiasi Merek $\left(\mathrm{X}_{3}\right)$

\begin{tabular}{|c|c|c|c|c|c|c|c|c|c|c|c|}
\hline \multirow{3}{*}{ Indikator } & \multicolumn{11}{|c|}{ Tanggapan Responden } \\
\hline & \multicolumn{2}{|c|}{ SS } & \multicolumn{2}{|c|}{$\mathbf{S}$} & \multicolumn{2}{|c|}{$\mathbf{N}$} & \multicolumn{2}{|c|}{ TS } & \multicolumn{2}{|c|}{ STS } & \multirow{2}{*}{ Mean } \\
\hline & $\sum$ & $\%$ & $\sum$ & $\%$ & $\sum$ & $\%$ & $\sum$ & $\%$ & $\sum$ & $\%$ & \\
\hline X3.1 & 3 & 4.0 & 25 & 33.3 & 33 & 44.0 & 9 & 12.0 & 5 & 6.7 & 3.2000 \\
\hline $\mathrm{X} 3.2$ & 10 & 13.3 & 30 & 40.0 & 24 & 32.0 & 10 & 13.3 & 1 & 1.3 & 3.5500 \\
\hline X3.3 & 5 & 6.7 & 29 & 38.7 & 30 & 40.0 & 10 & 13.3 & 1 & 1.3 & 3.3000 \\
\hline X3.4 & 20 & 26.7 & 42 & 56.0 & 8 & 10.7 & 3 & 4.0 & 2 & 2.7 & 4.0500 \\
\hline
\end{tabular}

Secara keseluruhan diketahui bahwa jawaban responden terhadap variabel asosiasi merek adalah mereka netral bahwa variabel ini mempengaruhi repurchase intention.

Tabel 4 Jawaban Responden Terhadap Indikator

Pertanyaan/Pernyataan Dimensi Loyalitas Merek $\left(\mathrm{X}_{4}\right)$

\begin{tabular}{|c|c|c|c|c|c|c|c|c|c|c|c|}
\hline \multirow{2}{*}{ Indikator } & \multicolumn{10}{|c|}{ Tanggapan Responden } \\
\cline { 2 - 14 } & \multicolumn{2}{|c|}{ SS } & \multicolumn{1}{|c|}{ S } & \multicolumn{2}{|c|}{ N } & \multicolumn{2}{|c|}{ TS } & \multicolumn{2}{|c|}{ STS } & \multirow{2}{*}{ Mean } \\
\cline { 2 - 13 } & $\sum$ & $\%$ & $\sum$ & $\%$ & $\sum$ & $\%$ & $\sum$ & $\%$ & $\sum$ & $\%$ & \\
\hline $\mathrm{X} 4.1$ & 2 & 2.7 & 24 & 32.0 & 38 & 50.7 & 9 & 12.0 & 2 & 2.7 & 3.3500 \\
\hline $\mathrm{X} 4.2$ & 7 & 9.3 & 48 & 64.0 & 16 & 21.3 & 3 & 4.0 & 1 & 1.3 & 3.9000 \\
\hline $\mathrm{X} 4.3$ & 4 & 5.3 & 19 & 25.3 & 38 & 50.7 & 13 & 17.3 & 1 & 1.3 & 3.0000 \\
\hline $\mathrm{X} 4.4$ & 15 & 20.0 & 39 & 52.0 & 19 & 25.3 & 1 & 1.3 & 1 & 1.3 & 3.9000 \\
\hline
\end{tabular}

Secara keseluruhan diketahui bahwa jawaban responden terhadap variabel loyalitas merek adalah mereka setuju bahwa variabel ini mempengaruhi repurchase intention. 
Tabel 5 Jawaban Responden Terhadap Indikator

Pertanyaan/Pernyataan Variabel Repurchase Intention

\begin{tabular}{|c|c|c|c|c|c|c|c|c|c|c|c|}
\hline \multirow{3}{*}{ Indikator } & \multicolumn{11}{|c|}{ Tanggapan Responden } \\
\hline & \multicolumn{2}{|c|}{ SS } & \multicolumn{2}{|c|}{$\mathbf{S}$} & \multicolumn{2}{|c|}{$\mathbf{N}$} & \multicolumn{2}{|c|}{ TS } & \multicolumn{2}{|c|}{ STS } & \multirow{2}{*}{ Mean } \\
\hline & $\sum$ & $\%$ & $\sum$ & $\%$ & $\sum$ & $\%$ & $\sum$ & $\%$ & $\sum$ & $\%$ & \\
\hline $\mathrm{Y} 1$ & 10 & 13.3 & 51 & 68.0 & 12 & 16.0 & 1 & 1.3 & 1 & 1.3 & 3.9000 \\
\hline $\mathrm{Y} 2$ & 3 & 4.0 & 22 & 29.3 & 40 & 53.3 & 8 & 5.3 & 2 & 2.7 & 3.3500 \\
\hline Y3 & 6 & 8.0 & 38 & 50.7 & 25 & 33.3 & 4 & 5.3 & 2 & 2.7 & 3.5500 \\
\hline
\end{tabular}

Secara keseluruhan dapat diketahui bahwa rata-rata jawaban responden terhadap indikator pada variabel ini adalah repurchase intention/ minat pembelian ulang handphone merek Samsung kepada mahasiswa fakultas ekonomi Universitas Tadulako di Kota Palu dapat dikatakan tinggi.

Tabel 6 Hasil Regresi

\begin{tabular}{|c|c|c|c|c|c|c|c|}
\hline \multicolumn{8}{|c|}{ Coefficients } \\
\hline \multirow{2}{*}{ No } & \multirow{2}{*}{\multicolumn{2}{|c|}{ Model }} & \multicolumn{2}{|c|}{$\begin{array}{l}\text { Unstandardized } \\
\text { Coefficients }\end{array}$} & \multirow{2}{*}{$\begin{array}{c}\text { Standardized } \\
\text { Coefficients } \\
\text { Beta }\end{array}$} & \multirow{2}{*}{$\mathrm{t}$} & \multirow{2}{*}{ Sig } \\
\hline & & & B & $\begin{array}{l}\text { Std. } \\
\text { Error }\end{array}$ & & & \\
\hline 1 & (Constant) & & -0.854 & 0.601 & & -1.421 & 0.160 \\
\hline 2 & Kesadaran Merek & & -0.011 & 0.084 & -0.011 & -0.131 & 0.896 \\
\hline 3 & Persepsi Kualitas ( & & 0.355 & 0.087 & 0.344 & 4.082 & 0.000 \\
\hline 4 & Asosiasi Merek (X & & 0.353 & 0.093 & 0.316 & 3.789 & 0.000 \\
\hline 5 & Loyalitas Merek (X & & 0.545 & 0.093 & 0.494 & 5.857 & 0.000 \\
\hline & R Square & $=0.515$ & F hitung & $=18.5$ & $\mathrm{~T}$ tabel & $=1.66$ & \\
\hline & Adjusted R Square & $=0.488$ & F Sig & $=0.0$ & $\alpha$ & $=0.05$ & \\
\hline & Multiple R & $=0.718$ & F tabel & $=2.50$ & & & \\
\hline
\end{tabular}

Bila hasil penelitian ini dimasukkan dalam formulasi matematis regresi linear berganda maka akan diperoleh untuk persamaan untuk penelitian ini sebagai berikut:

$$
Y=-0.854+(-0.011)\left(X_{1}\right)+0.355\left(X_{2}\right)+0.353\left(X_{3}\right)+0.545\left(X_{4}\right)
$$

Dimana:

1. a (constant) adalah -0.854. artinya jika kesadaran merek $\left(\mathrm{X}_{1}\right)$, persepsi kualitas $\left(\mathrm{X}_{2}\right)$, asosiasi merek $\left(\mathrm{X}_{3}\right)$ dan loyalitas merek $\left(\mathrm{X}_{4}\right)$ nilainya 0 maka repurchase intention handphone merek Samsung kepada mahasiswa Fakultas Ekonomi Universitas Tadulako di Kota Palu menjadi negatif yaitu -0.854 atau $-85.4 \%$.

2. Nilai koefisien regresi dimensi kesadaran merek $\left(X_{1}\right)$ bernilai -0.011 atau $-1,1 \%$. Hal ini menyatakan bahwa bila nilai kesadaran merek naik satu satuan, maka akan diikuti oleh penurunan repurchase intention handphone merek Samsung kepada mahasiswa Fakultas Ekonomi Universitas Tadulako di Kota Palu

3. Nilai koefisien regresi dimensi persepsi kualitas $\left(\mathrm{X}_{2}\right)$ bernilai 0.355 atau $35.5 \%$. Hal ini menyatakan bahwa bila nilai persepsi kualitas meningkat satu satuan, maka akan diikuti oleh kenaikan repurchase intention handphone merek Samsung kepada mahasiswa Fakultas Ekonomi Universitas Tadulako di Kota Palu

4. Nilai koefisien regresi dimensi asosiasi merek $\left(\mathrm{X}_{3}\right)$ bernilai 0.353 atau $35.3 \%$. Hal ini menyatakan bahwa bila nilai asosiasi merek meningkat satu satuan, maka akan diikuti oleh kenaikan repurchase intention handphone merek Samsung kepada mahasiswa Fakultas Ekonomi Universitas Tadulako di Kota Palu

5. Nilai koefisien regresi dimensi loyalitas merek $\left(\mathrm{X}_{4}\right)$ bernilai 0.545 atau $54.5 \%$. Hal ini menyatakan bahwa bila nilai loyalitas merek meningkat satu satuan, maka akan diikuti oleh 
kenaikan repurchase intention handphone merek Samsung kepada mahasiswa Fakultas Ekonomi Universitas Tadulako di Kota Palu

6. R Square adalah koefisien determinasi, yang menunjukkan presentase sumbangan variabel independen terhadap variabel dependen. Nilai R Square pada penelitian ini adalah 0.515 artinya persentase sumbangan pengaruh variabel kesadaran merek, persepsi kualitas, asoasiasi merek, dan loyalitas merek terhadap repurchase intention handphone merek Samsung kepada mahasiswa fakultas ekonomi Universitas Tadulako di kota Palu, sebesar 51.5\%, sedangkan sisanya sebesar $48.5 \%$ (100\%-51.5\%) dipengaruhi oleh variabel lain yang tidak dimasukkan dalam penelitian ini.

7. Nilai koefisien korelasi $R$ adalah 0.718 . nilai $R$ berkisar antara 0 sampai 1 , jika mendekati 0 maka hubungan semakin lemah. Nilai $R$ yang didapat pada penelitian ini adalah 0.718 yang artinya mempunyai hubungan atau korelasi yang kuat antara dimensi kesadaran merek, persepsi kualitas, asosiasi merek, dan loyalitas merek terhadap repurchase intention handphone merek Samsung kepada mahasiswa Fakultas Ekonomi Universitas Tadulako di Kota Palu, seperti pedoman yang dikemukakan oleh Sugiyono (dalam Wahyono, 2013:89) sebagai berikut:

Tabel 7 Pedoman Pengambilan Keputusan Korelasi

\begin{tabular}{|c|c|}
\hline Rentang Nilai Korelasi & Keputusan \\
\hline $0.00-0.199$ & Sangat Rendah \\
\hline $1.20-0.399$ & Rendah \\
\hline $0.40-0.599$ & Sedang \\
\hline $0.60-0.799$ & Kuat \\
\hline $0.80-1.000$ & Sangat Kuat \\
\hline
\end{tabular}

Sumber: Sugiyono (dalam Wahyono,2013:89)

\section{Hasil Pengujian Hipotesis pertama Uji Serempak (Uji F)}

Dari hasil analisis regresi linear berganda diperoleh nilai signifikansi F (sig F) $0,000<\alpha$ $(0,05)$, dengan demikian dapat diketahui bahwa variabel ekuitas merek yang terdiri dari kesadaran merek $\left(\mathrm{X}_{1}\right)$, persepsi kualitas $\left(\mathrm{X}_{2}\right)$, asosiasi merek $\left(\mathrm{X}_{3}\right)$, dan loyalitas merek $\left(\mathrm{X}_{4}\right)$, secara serempak berpengaruh signifikan terhadap repurchase intention handphone merek Samsung kepada mahasiswa Fakultas Ekonomi Universitas Tadulako di Kota Palu.

\section{Hasil Pengujian Hipotesis kedua Uji Parsial (Uji T)}

Berdasarkan Tabel 6, Hasil uji t untuk dimensi kesadaran merek diperoleh nilai tingkat signifikansi $0,895>\alpha(0,05)$, dengan demikian, kesadaran merek secara parsial tidak berpengaruh signifikan terhadap repurchase intention handphone merek Samsung kepada mahasiswa Fakultas Ekonomi Universitas Tadulako di Kota Palu.

Kesimpulan dari hasil uji regresi yang telah diamati bahwasanya mahasiswa khususnya mahasiswa fakultas Ekonomi Universitas Tadulako untuk melakukan pembelian ulang tidak lagi dipengaruhi oleh kesadaran akan suatu merek melainkan didasarkan pada pengalaman pembelian di masa lalu apakah dia puas atau tidak saat menggunakan produk tersebut, jika dia puas maka besar kemungkinan dia akan melakukan pembelian ulang terhadap merek yang sama tapi jika dia tidak puas maka besar kemungkinan dia tidak akan melakukan pembelian kembali walaupun merek tersebut sudah tertanam kuat dibenaknya. Fenomena ini terjadi dikarenakan mahasiswa lebih cenderung melakukan evaluasi terhadap sebuah produk atau merek yang pernah dia gunakan, mahasiswa tidak lagi peduli bahwa merek atau produk tersebut sering muncul dalam bauran promosi, ketika hasil evaluasi ternyata tidak sesuai dengan harapan maka dia akan tetap tidak akan melakukan pembelian ulang terhadap produk tersebut. 


\section{Hasil Pengujian Hipotesis ke Tiga Uji Parsial (Uji t)}

Berdasarkan Tabel 6 Hasil uji t untuk dimensi persepsi kualitas diperoleh nilai tingkat signifikansi $0,000<\alpha(0,05)$, dengan demikian, persepsi kualitas secara parsial berpengaruh signifikan terhadap repurchase intention handphone merek Samsung kepada mahasiswa Fakultas Ekonomi Universitas Tadulako di Kota Palu.

Hasil ini menyimpulkan bahwa asosiasi merek berpengaruh signifikan terhadap repurchase intention handphone merek Samsung kepada mahasiswa fakultas ekonomi universitas Tadulako . Hal ini berarti peningkatan asosiasi merek, akan meningkatkan secara repurchase intention handphone merek Samsung kepada mahasiswa fakultas ekonomi universitas Tadulako

\section{Hasil Pengujian Hipotesis ke Empat Uji Parsial (Uji t)}

Berdasarkan Tabel 5.15, Hasil uji t untuk dimensi asosiasi merek diperoleh nilai tingkat signifikansi $0,000<\alpha(0,05)$. Dengan demikian, asosiasi merek secara parsial berpengaruh signifikan terhadap repurchase intention handphone merek Samsung kepada mahasiswa Fakultas Ekonomi Universitas Tadulako di Kota Palu.

Kesimpulan dari hasil uji regresi bahwa mahasiswa Fakultas Ekonomi Universitas Tadulako akan cenderung melakukan pembelian ulang akan suatu produk yang mempunyai kesan-kesan yang baik di dalam ingatanya, hal ini dikarenakan secara psikologis mahasiswa akan menyukai sesuatu hal yang sudah mempunyai citra positif di mata masyarakat dan adanya kesan positif yang kuat saat penggunaan terhadap merek tersebut di masa lalu sehingga hal inilah menjadi pertimbangan yang kuat untuk mahasiswa Fakultas Ekonomi Universitas Tadulako akan melakukan pembelian kembali dengan merek yang sama.

\section{Hasil Pengujian Hipotesis ke Lima Uji Parsial (Uji t)}

Berdasarkan Tabel 5.15, Hasil uji t untuk dimensi loyalitas merek diperoleh nilai tingkat signifikansi $0,000<\alpha(0,05)$. Dengan demikian, loyalitas merek secara parsial berpengaruh signifikan terhadap repurchase intention handphone merek Samsung kepada mahasiswa Fakultas Ekonomi Universitas Tadulako di Kota Palu.

Kesimpulan dari hasil uji regresi bahwa mahasiswa Fakultas Ekonomi Universitas Tadulako akan loyal terhadap sesuatu merek ketika sudah ada ikatan yang kuat diantara mereka, hal ini bisa terjadi dikarenakan merek tersebut sudah sangat sesuai dengan harapanya dan secara psikologis sudah mempunyai komitmen untuk terus menggunakan merek yang sama, dan melihat fenomena yang terjadi mahasiswa lebih cenderung akan setia menggunakan suatu merek ketika dia sudah mendapatkan suatu produk dengan merek tertentu yang sesuai dengan karakternya atau harapanya, bahkan jika dilihat bahwasanya dimensi loyalitas merek mempunyai pengaruh terbesar diantara dimensi yang lain, dimana loyalitas merek memberikan sumbangan pengaruh sebesar $54.5 \%$. terhadap minat pembelian ulang (repurchase intention).

\section{KESIMPULAN DAN SARAN}

\section{Kesimpulan}

Berdasarkan uraian hasil dan pembahasan tersebut, maka kesimpulan yang dapat ditarik dari penelitian ini yaitu sebagai berikut:

1. Hasil pengujian Hipotesis I, Variabel ekuitas merek yang terdiri dari dimensi kesadaran merek (X1), persepsi kualitas (X2), asosiasi merek (X3) dan loyalitas merek secara serempak berpengaruh signifikan terhadap repurchase intention handphone merek Samsung kepada mahasiswa Fakultas Ekonomi Universitas Tadulako di Kota Palu.

2. Hasil pengujian terhadap hipotesis II dengan menggunakan metode regresi linear berganda menyatakan bahwa secara parsial kesadaran merek $\left(X_{1}\right)$ tidak mempunyai pengaruh yang signifikan terhadap repurchase intention handphone merek Samsung kepada mahasiswa Fakultas Ekonomi Universitas Tadulako di Kota Palu.

3. Hasil pengujian terhadap hipotesis III dengan menggunakan metode regresi linear berganda menyatakan bahwa secara parsial persepsi kualitas $\left(\mathrm{X}_{2}\right)$ mempunyai pengaruh yang signifikan terhadap repurchase intention handphone merek Samsung kepada mahasiswa Fakultas Ekonomi Universitas Tadulako di Kota Palu. 
4. Hasil pengujian terhadap hipotesis IV dengan menggunakan metode regresi linear berganda menyatakan bahwa secara parsial asosiasi merek $\left(\mathrm{X}_{3}\right)$ mempunyai pengaruh yang signifikan terhadap repurchase intention handphone merek Samsung kepada mahasiswa Fakultas Ekonomi Universitas Tadulako di Kota Palu.

5. Hasil pengujian terhadap hipotesis $\mathrm{V}$ dengan menggunakan metode regresi linier berganda menyatakan bahwa secara parsial loyalitas merek $\left(\mathrm{X}_{4}\right)$ mempunyai pengaruh yang signifikan terhadap repurchase intention handphone merek Samsung kepada mahasiswa Fakultas Ekonomi Universitas Tadulako di Kota Palu.

\section{Saran}

Berdasarkan uraian hasil penelitian dan kesimpulan, maka ada beberapa hal yang dapat di rekomendasikan kepada pihak-pihak terkait dengan penelitian ini sebagai berikut:

1. Karena kepemilikan ekuitas merek handphone Samsung yang selama ini dimilikinya, terdapat beberapa hal yang harus menjadi perhatian, yakni variabel persepsi kualitas, asosiasi merek dan loyalitas merek mempunyai pengaruh yang signifikan, maka perusahaan harus terus meningkatkan kualitas produk, meningkatkan pencitraan merek, terus melakukan inovasi agar sesuai dengan gaya hidup sehingga menarik konsumen untuk melakukan pembelian ulang atau repurchase intention.

2. Karena ekuitas merek adalah aset yang tidak kelihatan yang keberadaanya cukup berpengaruh pada penghasilan perusahaan, maka penelitian seperti ini harus menjadi pertimbangan dalam pengambilan kebijakan perusahan.

3. Kepada peneliti selanjutnya diharapkan yang meneliti mengenai ekuitas merek terhadap repurchase intention handphone merek Samsung kepada mahasiswa Fakultas Ekonomi Universitas Tadulako di Kota Palu, untuk dapat mengkombinasikan variabel-variabel lain yang mempengaruhi untuk melakukan repurchase intention agar hasil didapatkan akan lebih maksimal.

\section{REFERENSI}

Agusli, Devonalita, dan Yohanes Sondang Kunto. 2013. Analisa Pengaruh Dimensi Ekuitas Merek Terhadap Minat Beli Konsumen Midtown Hotel Surabaya. Jurnal Manajemen 2, Hal. 18.Pemasaran Petra, Vol. 1, No.1-8.

Amir, M.Taufiq, 2005. Dinamika Pemasaran Jelajahi \& Rasakan. PT. Raja Grafino Persada, Jakarta.

Baihaki, Imam, 2015. Sejarah Perkembangan handphone Samsung, Diakses Kamis 15 Oktober 2015. http://www.beritateknologi.com/sejarah-perkembangan-handphone-pintar-samsung/

Chan, Arianis. 2010, Pengaruh Ekuitas Merek Terhadap Proses Keputusan Pembelian Konsumen :Studi Kasus Bank Muamalat Indonesia Cabang Bandung. Jurnal Aministrasi Bisnis, Vol 6, No. 1, Hal. 43-58, (ISSN: 0216-1249).

Deby, Susanti Sudarsono dan Dyah Kurniawati (2013). Elemen ekuitas merek dalam keputusan pembelian laptop. Jurnal Riset Manajemen dan Akuntansi Vol. 1 No. 1, Februari 2013

Diana, Puspitasari, (2006). Analisis Pengaruh Persepsi Kualitas Dan Keputusan Pelanggan Terhadap Minat Beli Ulang (Studi Kasus Pada Maskapai Pernebangan Garuda Keberangkatan Semarang).

Durianto, Darmadi, Sugiarto, dan Tony S. 2004. Strategi Menaklukkan Pasar Melalui Riset Ekuitas dan Perilaku Merek. Jakarta: PT.Gramedia Pustaka Utama.

Firdaus. 2004. Statistik Parametrik: Regresi Linear Berganda dan Problematikanya, PT Rinata Cipta, Jakarta.

Giffar, Davinindya. 2016. Peran Iklan, Brand Image, Price, Trust, dan Percieved Value Terhadap Repurchase Intention Traveloka.

Hafizah, 2012. Hubungan Kepercayaan Merek Dan Kualitas Produk Telkomsel Flash Terhadap Kepuasan Konsumen di PT.Telkomsel Grapari Medan Selecta. Jurnal Keuangan \& Bisnis, Vol.4, No.1, Maret 2012

Hadi, Prasetyo dan Sumarto (2010). Pentingnya Brand Loyalty Terhadap Minat Beli Ulang. Jurnal Riset Ekonomi dan Bisnis Vol.10 No. 1 Maret 2010 
Nursyamsu, S.

Hellier, Philip K, Geursen Gus M, Carr Rodney A, and Rickard John A, 2003. Customer Repurchase Intention : A General Structural Equation Model, Journal Of Marketing, Vol.37, pp:17621800)

Kotler, Philip, Kevin Lane Keller. 2008. Manajemen Pemasaran $13^{\text {th }}$ ed.PT Gelora Aksara Pratama, Jakarta.

Lawu, Bakti Jean Lawas (2015). Pengaruh elemen brand knowledge dan brand

equity terhadap repurchase intention. Jurnal Manajemen, Vol.14, No.2, Mei 2015

Prastiwi, Septi Kurnia (2012). Analisis anteseden loyalitas dan WOM serta pengaruhnya terhadap repurchase intention pada produk susu SGM (studi pada orang tua siswa teman sejati sari husada Yogyakarta). Riset manajemen dan akuntansi Volume 3 Nomor 6 Edisi November 2012.

Saputra, Aswin , 2012. Pengaruh Ekuitas Merek Terhadap Pengambilan Keputusan pembelian Handphone merek Blackberry (Studi Pada Mahasiswa Fakultas Ekonomi dan Bisnis Universitas Hasanuddin).

Simamora, Bilson. 2003. Membongkar Kotak Hitam Konsumen. Jakarta: Gramedia Pustaka Utama

Solimun. 2002. Multivariate Analysis Structural Equation Modelling (SEM), Lisrel Dan Amos: Aplikasi Di Manajemen, Ekonomi Pembangunan, Psikologi, Sosial, Kedokteran Dan Agrokompleks. Malang: Universitas Negeri Malang.

Sudarmanto, R.gunawan. 2013. Statistik terapan berbasis computer dengan Program IBM SPSS Statistic 19, MitraWacana Media, Jakarta.

Sudarsono, Deby Susanti, Dyah Kurniawati, 2013. Elemen Ekuitas Merek Dalam Keputusan Pembelian Laptop. Jurnal Riset Manajemen dan Akuntansi, Vol 1, No. 1, February 2013.

Sugiyono, 2014. Metode Penelitian Bisnis, CV.Alfabeta, Bandung.

Trisnawati, Ella, Agus Suroso, Untung Kumorohadi (2012). Analisis faktor-faktor kunci dari niat pembelian kembali secara online (study kasus pada konsumen Fesh Shop). Jurnal bisnis dan ekonomi (JBE), September 2012, Hal. 126 -141 (ISSN: 1412-3126)

Wahyono, Dwi. 2013. Pengaruh Gaya Hidup Remaja Terhadap Keputusan Pembelian Handphone Blacberry Di Kota Palu. Jurnal Ilmiah Ekonomi Bisnis STIE Panca Bhakti Palu Vol.16. 